\title{
Cellular energy status is indispensable for perillyl alcohol mediated abrogated membrane transport in Candida albicans
}

\author{
Moiz A. Ansari, Zeeshan Fatima* and Saif Hameed* \\ Amity Institute of Biotechnology, Amity University Haryana, Gurgaon (Manesar)-122413, India.
}

*Corresponding Authors: Dr. Saif Hameed and Dr. Zeeshan Fatima, Amity Institute of Biotechnology, Amity University Haryana, Gurgaon (Manesar)-122413, India. Email: saifhameed@yahoo.co.in, drzeeshanfatima@gmail.com ; Tel.: +91124-2337015, Ext: 1116.

Received: April 21, 2017; Revised: May 23, 2017; Published: June 22, 2017

\begin{abstract}
The prevalence of fungal infections and their resistance patterns in fungal isolates from large number of patients with impaired immunity still remains poorly monitored. In spite of significant advances being made in the improvement of antifungal drugs, only a limited number of antifungal drugs are currently available. The present study aimed to gain further mechanistic insights into the previously described anticandidal activity of natural monoterpenoid, perillyl alcohol (PA). We found that cellular transport across cell membrane was abrogated in presence of PA. This was demonstrated by dose and time dependent enhanced cellular leakage accompanied by inhibited sodium and potassium cellular transport. In addition, we found disrupted $\mathrm{pH}$ homeostasis which was depicted by enhanced extracellular $\mathrm{pH}$. We further observed that mitochondrial energy status is highly integrated with the antifungal activity of PA. This was evident from inhibited propidium iodide (PI) uptake in presence of sodium azide and di-nitro phenol (DNP) which showed no fluorescence when treated with PA. Moreover, we observed that PA leads to disrupted mitochondrial membrane potential. Additional cell death hallmarks in response to PA such as nuclear fragmentation was also observed with 4',6-diamidino-2-phenylindole (DAPI) staining. Taken together, PA is a novel candidate that deserves further attention to be exploited as effective antifungal agent of pharmacological interest.
\end{abstract}

\section{Keywords}

Perillyl alcohol; sodium transport; potassium transport; $\mathrm{pH}$ homeostasis; mitochondria; ATP; DNA damage

\section{Introduction}

Candida albicans being an opportunistic human fungal pathogen resides commensally within the host. However, under immune-compromised conditions such as organ transplantation, chemotherapy and diabetes, it turns up into a deadly pathogen [1]. According to the recent finding, around 1.5 million people died per annum due to invasive fungal infections [2] and among all fungal pathogens Candida species leads the toll for the cause of the mortality related to the mycotic death throughout the world [3]. With the limited repertoire of current therapeutics which includes antifungal drugs from three major classes; azoles, polyenes and echinocandins, the utility of these drugs are restricted due to high cost and sometimes host toxicity. Moreover, emergence of drug resistant strains due to the phenomenon of multidrug resistance 
(MDR) has compounded the problem and became major obstacle against effective therapeutics [4]. Therefore, the flux towards phytochemical research to circumvent the problem of MDR in need of new antifungals is in serious vigilance nowadays.

We previously demonstrated that perillyl alcohol (PA) is a natural benzylic monoterpenoid (Fig. 1), similar to its class terpenoid [5], it also showed immense antifungal potential against human pathogen $C$. albicans as well as non-albicans species of Candida [6]. However, PA is immensely studied for its anticancerous activities and recently reported as suitable for brain tumor therapy [7-9]. Moreover, PA is FDA approved food additive that can be safely consumed without any toxic effect. The current study enhances the knowledge of mechanistic action of PA induced membrane disruption against $C$. albicans leading to the altered cationic concentration and demonstrates that cellular energy status is indispensable for functional anticandidal activity of PA. Additionally, we explored that PA leads to disrupted mitochondrial membrane potential and nuclear fragmentation.

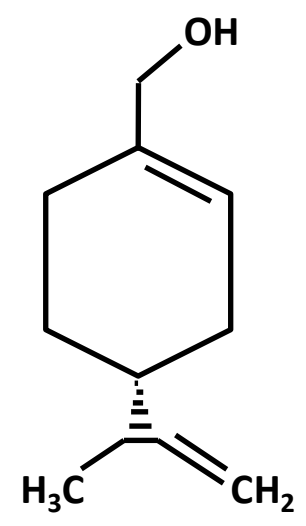

Figure 1. Chemical structure of PA

\section{Experimental}

\section{Materials}

Yeast extract, di-nitro phenol (DNP) and peptone were purchased from Himedia, India. D-Glucose, dimethyl sulfoxide (DMSO), rhodamine $\mathrm{B}, \mathrm{NaN}_{3}$ and $\mathrm{KCl}$ were purchased from Thermofisher. Fluconazole (FLC) DAPI and PA were purchased from Sigma.

\section{Cellular leakage}

Analysis of loss of cellular material absorbing at $260 \mathrm{~nm}$ from Candida cell was performed using the method described elsewhere with little modifications [10]. Briefly, Candida cells were grown in YPD at $30^{\circ} \mathrm{C}$ for $48 \mathrm{~h}$ and cell suspension $\left(\mathrm{OD}_{600}\right.$ as 1 ) was prepared in $10 \mathrm{~mL}$ PB. Furthermore, this suspension was treated with different concentrations $(1 \times, 2 \times$, and $4 \times \mathrm{MIC})$ of PA and FLC for $1 \mathrm{~h}$ or at fixed concentration (1× MIC) for different time intervals $(30,60,90$ and $120 \mathrm{~min})$. Untreated sample was run as negative control. After treatment, samples were centrifuged at $10,000 \mathrm{rpm}$ for $10 \mathrm{~min}$ at $4{ }^{\circ} \mathrm{C}$, and the absorbances of supernatants were read at $260 \mathrm{~nm}$ using UV-vis spectrophotometer (VSI-501, India).

\section{Intracellular $\mathrm{Na}^{+}$concentration}

Intracellular sodium ion concentration was obtained as described elsewhere with slight modification [11]. Briefly, cells were pre-grown at $30^{\circ} \mathrm{C}$ in YNB medium overnight. The cells were inoculated into $50 \mathrm{~mL}$ of YNB medium (with and without drug) to obtain OD600 as 0.05 and grown at $30^{\circ} \mathrm{C}$ to obtain OD600 between 0.17-0.3; and the intracellular sodium content was measured. To estimate the intracellular $\mathrm{Na}^{+}$ 
concentration, cell pellets, after harvesting and washing with water, were suspended in $18 \mathrm{~mL}$ of incubation buffer $\left(20 \mathrm{mmol} / \mathrm{L} \mathrm{MES}\right.$ and $0.1 \mathrm{mmol} / \mathrm{L} \mathrm{MgCl} 2, \mathrm{pH} 5.5$ adjusted by solid $\left.\mathrm{Ca}(\mathrm{OH})_{2}\right)$. Cells were washed twice with washing buffer $\left(20 \mathrm{mmol} / \mathrm{L} \mathrm{MgCl}_{2}\right)$ and lysed in $5 \mathrm{~mL}$ of extraction buffer $(10 \mathrm{mmol} / \mathrm{L}$ $\mathrm{MgCl}_{2}$ and $0.2 \mathrm{~mol} / \mathrm{L} \mathrm{HCl}$ ). Flame photometer (Systronics, India) was used to determine the sodium content in the extracts.

\section{$K^{+}$leakage estimation}

Estimation of extracellular $\mathrm{K}^{+}$leakage from the fungal cell was performed using the method described elsewhere with little modifications [11]. Briefly, Candida cells were grown in $100 \mathrm{~mL}$ YPD at $30^{\circ} \mathrm{C}, 120 \mathrm{rpm}$ for $24 \mathrm{~h}$. Cell pellets were harvested at $5000 \mathrm{rpm}$ for $5 \mathrm{~min}$ and washed three times with sterile phosphate buffer (PB) and suspended in $10 \mathrm{~mL}$ of PB. $500 \mu \mathrm{L}$ of the cell suspension was used to determine dry cell weight. $2 \mathrm{~mL}$ of cell suspension was mixed with $2 \mathrm{~mL}$ of PB containing desired concentration $(1 \times, 2 \times$ and 4 $\times$ MIC) of test agents and incubated for $4 \mathrm{hr}$. After treatment samples were centrifuged at 10,000 rpm for $10 \mathrm{~min}$, and supernatant was removed and stored for the determination of extracellular $\mathrm{K}^{+}$content released into the medium. The $\mathrm{K}^{+}$concentration was estimated by Flame Photometer (Systronics, India) using potassium filter.

\section{PM-ATPase mediated proton pumping}

The proton pumping activity of $C$. albicans was estimated by monitoring the glucose-induced acidification of the external medium due to $\mathrm{pH}$ changes as previously reported [12]. Briefly, overnight cultures of $C$. albicans were grown in YEPD broth for $18 \mathrm{~h}$ at $30^{\circ} \mathrm{C}$. The cells were collected by centrifugation at $3000 \mathrm{~g}$ for $5 \mathrm{~min}$ at $4{ }^{\circ} \mathrm{C}$ and washed with sterile distilled water and $50 \mathrm{mM} \mathrm{KCl}(\mathrm{pH} \mathrm{6.5)}$. The washed cells were resuspended in $40 \mathrm{ml}$ of $50 \mathrm{mM} \mathrm{KCl}\left(\mathrm{pH} \mathrm{6.5)}\right.$ and incubated at $4^{\circ} \mathrm{C}$ overnight to deplete their carbon reserves. The carbon-starved cells were harvested by centrifugation, and approximately $1.0 \mathrm{~g}$ wet weight of the pellet was resuspended in $40 \mathrm{ml}$ of $50 \mathrm{mM} \mathrm{KCl}$ (pH 6.5). To a $40 \mathrm{ml}$ aliquot of the cell suspension, PA at MIC80 was added to obtain the required concentration and mixed well, and the volume was adjusted to $45 \mathrm{ml}$ with $50 \mathrm{mM} \mathrm{KCl}$. The cell suspension was incubated at room temperature with gentle stirring for $10 \mathrm{~min}$, and then $5 \mathrm{ml}$ of $20 \%$ glucose (final concentration, $55 \mathrm{mM}$ ) was added and the $\mathrm{pH}$ of the external medium was monitored at regular intervals for $40 \mathrm{~min}$ at indicated time points. The experiment was performed in the presence of a comparable concentration of the solvent DMSO (control) to measure the extent of acidification of the external medium in the absence of PA.

\section{Propidium iodide uptake}

Propidium iodide, is a dye impermeable to membrane and is widely used to differentiate cells that have damaged plasma membranes from healthy cells [13]. To evaluate the effect of PA on the fungal plasma membrane, C. albicans SC5314 cells (approximately $1 \times 103$ CFUs/ml) were obtained from exponential phase and exposed to PA $(225 \mu \mathrm{g} / \mathrm{ml})$ for $3 \mathrm{~h}$ at $30{ }^{\circ} \mathrm{C}$ with gentle shaking. Subsequently, cells were harvested, incubated with propidium iodide for $15 \mathrm{~min}$, and observed by Coslab fluorescence microscope.

\section{Mitochondrial membrane potential $\left(m t \Psi_{m}\right)$}

Rhodamine $B$ dye (Molecular Probes) was used to detect the change of mitochondrial membrane potential [14]. C. albicans (SC5314) cells were treated with PA $(225 \mu \mathrm{g} / \mathrm{ml})$ overnight at $30{ }^{\circ} \mathrm{C}$. The treated cells were washed in PBS and then suspended in $40 \mathrm{nM}$ rhodamine $\mathrm{B}$ for $20 \mathrm{~min}$ at $37^{\circ} \mathrm{C}$. The cells were centrifuged at $500 \mathrm{~g}$ for $5 \mathrm{~min}$ and the pellet was re-suspended in $1 \mathrm{~mL}$ PBS. The cells were analyzed using Coslab fluorescence microscope and fluorescent intensity was measured through Image J software. All 
observations were confirmed with 3 independent cell cultures.

\section{DAPI staining}

Cells were stained with DAPI to detect nuclear fragmentation as discussed elsewhere [15]. The strains were grown in YEPD overnight in presence of PA at $30{ }^{\circ} \mathrm{C}$. Fragmented nuclei were identified by staining with $0.1 \mu \mathrm{g} / \mathrm{mL}$ DAPI for $15 \mathrm{~min}$. The stained cells were collected then washed twice with $1 \%$ BSA in PBS for 5 min followed by a five minute rinse in $0.1 \%$ BSA in PBS. Cells were visualized with Coslab fluorescence microscope. All observations were confirmed with 3 independent cell cultures.

\section{Results and Discussion}

Membrane disruption by PA leads to cellular leakage in C. albicans

In our previous study we have determined that anticandidal effect of PA is mediated through membrane perturbation [6]. In this study we have explored the severity of this damage in terms of transport across cell membrane. For this, cellular leakage across membrane was estimated by the leakage of intracellular components. A cellular component that absorbs light of $260 \mathrm{~nm}$ wavelength signifies for a particular class of out-flowing components, mainly nucleotides which include uracil compounds revealing strongest absorbance [10]. In the PA treated cells similar to FLC, the absorbance of intracellular content was observed to be increased for PA in dose dependent manner (Figure 2a). We further confirmed the cellular leakage by studying time kinetics at MIC concentration of PA. We observed the elevation in absorbance from the cells treated with PA and FLC with respect to time till $120 \mathrm{~min}$ (Figure $2 \mathrm{~b}$ ). This proves that the PA treatment enhances the leakage of cellular contents through membrane disruption.

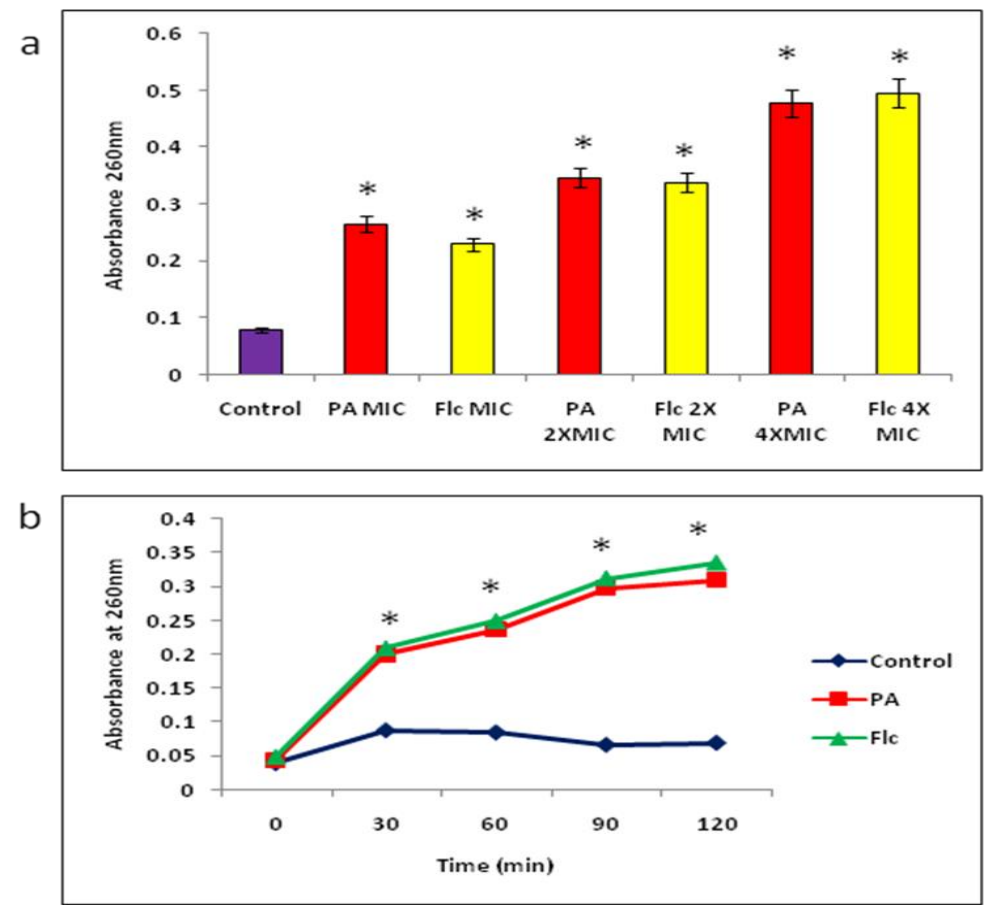

Figure 2. Effect of PA and FLC on 260nm absorbing material in C. albicans: (a) concentration dependent, (b) time dependent.

\section{PA affects $\mathrm{Na}^{+}$transport and $\mathrm{pH}$ homeostasis in C. albicans}

Enhanced cellular leakage in presence of PA prompted us to study the transport of ions across the membrane more closely. To verify that the leakage of cellular content due to PA treatment is also affecting 
cationic concentration, the intracellular $\mathrm{Na}^{+}$concentration was evaluated. It was observed that the $\mathrm{Na}^{+}$ concentration was significantly decreased in the PA treated cells which suggests that PA induced membrane disruption possibly affects $\mathrm{Na}^{+}$transport across the membrane (Figure 3a).

The two main transporters in yeast that are accountable for alkali-metal-cation permeability across the membrane are $\mathrm{Na}^{+} / \mathrm{H}^{+}$antiporter and a $\mathrm{Na}^{+}$-ATPase. Both transporters harmonize each other to support detoxification. The $\mathrm{Na}^{+} / \mathrm{H}^{+}$antiporter is active during low extracellular $\mathrm{pH}$ however $\mathrm{Na}^{+}-$ATPase is highly active at neutral and higher extracellular $\mathrm{pH}$ [16]. Thus we checked that if the decrease in $\mathrm{Na}^{+}$ concentration is linked with some changes in extracellular $\mathrm{pH}$. It was seen that the PA treatment leads to the significant increment in the extracellular $\mathrm{pH}$ in the Candida cells (Figure $3 \mathrm{~b}$ ). While convalescing themselves during starvation, Candida cells pump intracellular protons outside the cell through plasma membrane ATPase, utilizing available number of ATP after the addition of glucose to non-growing nutrient deficient cells. Thus, proton pumping action of the ATPase could be the reason for acidification of the medium. This confirms that PA treated Candida cells lost the ability to pump intracellular protons to the external medium may be due to inhibition in plasma membrane ATPase thereby elevating the $\mathrm{pH}$ of the external medium and diminishing the intracellular $\mathrm{Na}^{+}$concentration.

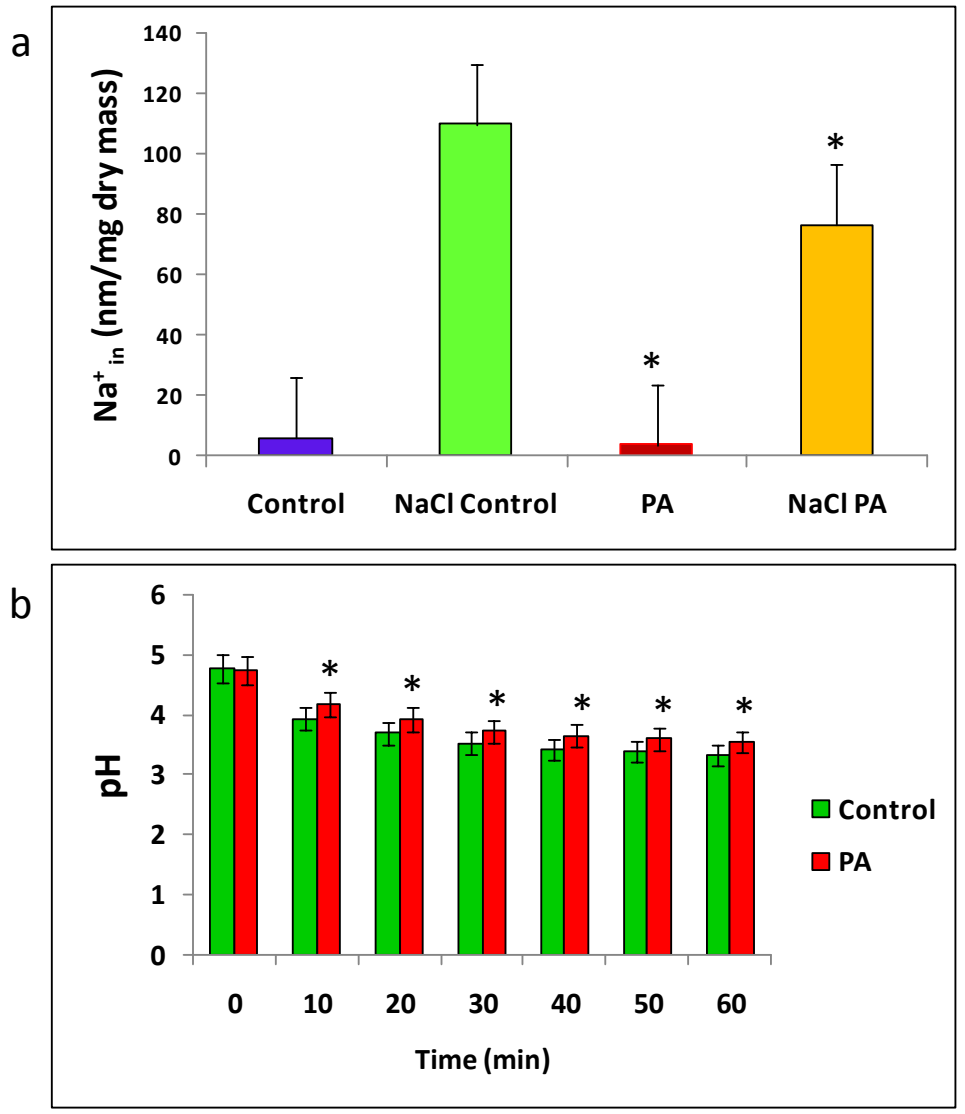

Figure 3. Effect of PA on membrane permeability in C. albicans: (a) effect of PA on intracellular $\mathrm{Na}^{+}$ concentration (b) effect of PA on the glucose-dependent acidification of the medium by $C$. albicans cells.

Mean of $\mathrm{pH} \pm \mathrm{SD}$ of three independent sets of experiments are shown in absence (control) and presence of PA with respect to time (minutes) and $* P$ value $<0.05$ is considered to be significant.

\section{PA affects $K^{+}$transport in C. albicans}

As a known matter of fact, $\mathrm{Na}^{+}$transport across cellular membrane is linked with $\mathrm{K}^{+}$transport. Moreover, the concentration both of $\mathrm{Na}^{+}$and $\mathrm{K}^{+}$plays a critical role to maintain the membrane potential in the cells [17]. In fact dysregulation of ion homeostasis forms the basis of cell death for many terpenoids. 
Thus we checked whether there are also some changes in $\mathrm{K}^{+}$transport in presence of PA. This was evident from the elevated level of intracellular and diminished levels of extracellular $\mathrm{K}^{+}$concentration respectively in PA treated cells (Figure 4). This result suggests that the $\mathrm{Na}^{+}-\mathrm{K}^{+}$antiporters may be affected in presence of PA. From these observations, one may also speculate that enhanced membrane permeability due to PA could cause dissipation of ionic gradient across cell membrane leading to membrane depolarization, however, further work is needed to confirm.

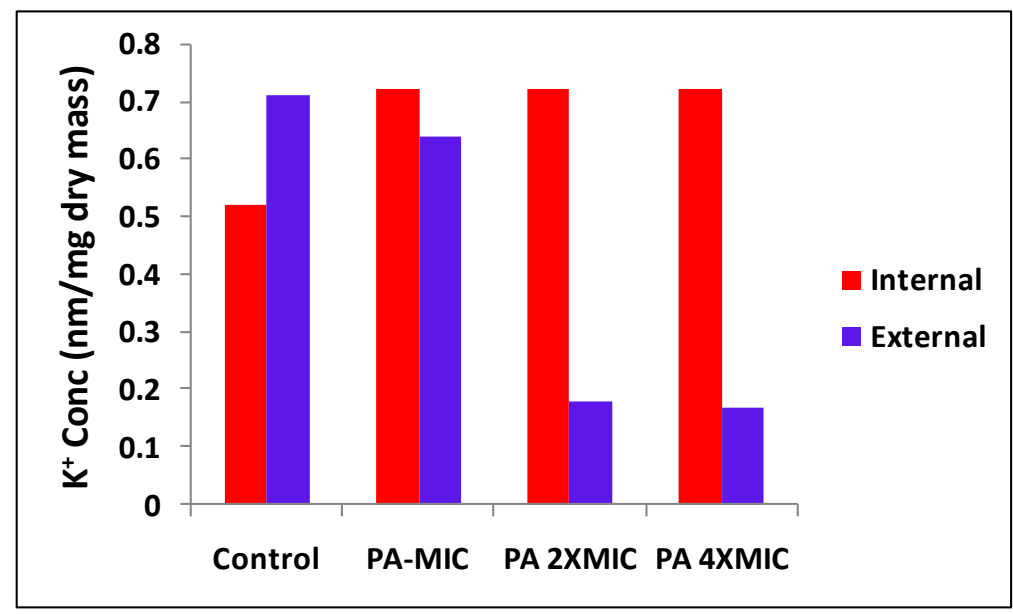

Figure 4. Effect of PA on intracellular and extracellular $\mathrm{K}^{+}$concentration in C. albicans

\section{Membrane perturbations due to PA is energy dependent}

Sodium azide and DNP is known for ATP reducing property by decreasing the amount of ATP in Candida cells targeting cytochrome oxidase of mitochondria and binds with the heme a3 iron and $\mathrm{CuB}$ in the reduction site of oxygen $[18,19]$. F1 domain is also an important component of mitochondria for its ATP generation ability. It is the assembly of alternatively arranged three $\alpha$ and three $\beta$ subunits around the central stalk, which is made of $\gamma, \delta$ and $\varepsilon$ subunits. Azide binds to the F1 catalytic domain and inhibits ATP hydrolysis [20]. To study whether the membrane disruptive action of PA is energy dependent, an assay was performed through PI uptake of sodium azide treated cells in the presence of PA (Figure 5). We observed that in cells that were not treated by sodium azide or DNP, PI uptake was efficient and showed fluorescence when treated with PA. However in the sodium azide or DNP treated cells this effect of PA was reverted and no cell was stained with PI. These observations not only confirmed non-intact membrane confirming our previous hypothesis of membrane disruption [6] but also suggests that the intracellular localization and the membrane damaging effect of PA is energy dependent.

\section{PA alters mitochondrial membrane potential $\left(m t \Psi_{m}\right)$ in C. albicans}

In our previous study we documented that PA inhibits the mitochondrial enzyme functioning [6]. Moreover, $\mathrm{mt} \psi_{\mathrm{m}}$ is a sensitive indicator of the energy status of the mitochondria which is the result of an electrochemical gradient maintained through the electron transport chain and also plays key role in ATP synthesis which is derived from mitochondrial oxidative phosphorylation [21]. Hence, we study the effect of $\mathrm{PA}$ on $\mathrm{mt} \Psi_{\mathrm{m}}$ by employing Rhodamine $\mathrm{B}$ probe as described in material and methods. Rhodamine $\mathrm{B}$ spreads throughout the biological membranes in response to the $\Psi_{\mathrm{m}}$. The change in mitochondrial potential $\left(\Delta \Psi_{\mathrm{m}}\right)$ directly correlates with the increase or decrease in ATP content of the cells, where higher the $\Delta \psi_{\mathrm{m}}$ more will be the cellular ATP level [14]. In the intact cells, the fluorescence of rhodamine $B$ tends to decrease because of the formazan, quencher of rhodamine B which naturally accumulates in mitochondrial matrix, hence $\Delta \Psi_{\mathrm{m}}$ will be more. However in mitochondria disrupted cells the $\Delta \Psi_{\mathrm{m}}$ will be 
less due to no quenching in fluorescence depicted by red signals $[14,22]$. Our result clearly demonstrates that PA treated Candida cells showed more fluorescence (Figure 6) which suggests that PA alters the $\mathrm{mt} \Psi_{\mathrm{m}}$ in C. albicans.

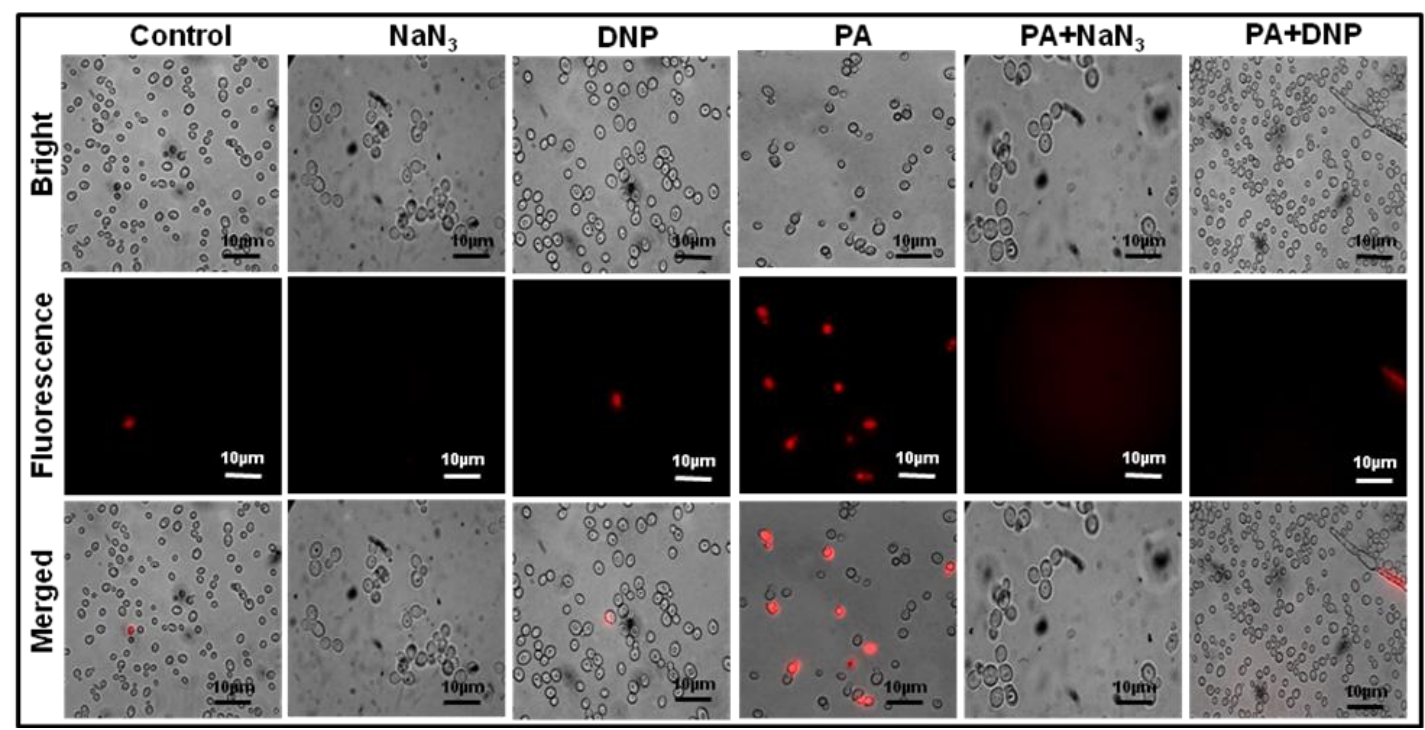

Figure 5. Effect of energy depletion on anticandidal activity of PA. Fluorescent microscopy of PI in presence of $5 \mathrm{mM} \mathrm{NaN}_{3}$ and DNP.
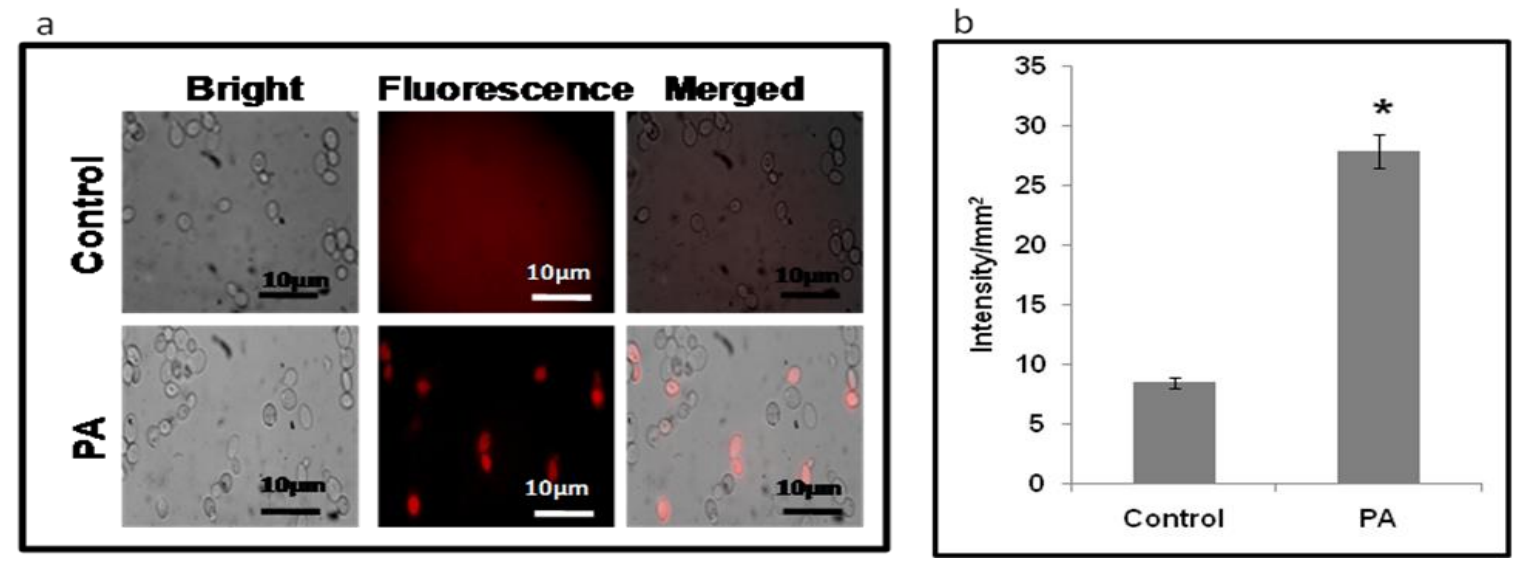

Figure 6. Effect of PA on $\mathrm{mt} \psi_{\mathrm{m}}$ : a) Fluorescent microscopy of Rhodamine B for analysis of $\mathrm{mt} \psi_{\mathrm{m}}$ in presence of PA b) Fluorescent intensity of untreated (control) and PA treated cells and ${ }^{*} \mathrm{P}$ value $<0.05$ is considered to be significant.

\section{PA induces nuclear fragmentation in C. albicans}

Mitochondria dysfunctioning is one of the major causes that lead to the DNA damage [15]. Moreover, the leakage of intracellular content primarily nucleotides from this study and hypersensitivity towards PA in presence of DNA damaging agent from previous observation was enough evidence to study nuclear fragmentation [6]. Hence we checked the nuclear fragmentation using DAPI staining as described in material and methods. DAPI is a fluorescent dye that binds to the AT site between the minor groove of DNA. The fluorescence can be evaluated with irregular margin and condensed chromatin [15]. We found that the cells treated with PA showed nuclear fragmentation which could be linked with DNA damage (Figure 7). Since damaged DNA cannot replicate owing to prevention of mutations, cell cycle is arrested [23]. This observation is also commensurate with our earlier findings which showed PA induced down 
regulation of several DNA repair genes and cell cycle arrest [6].

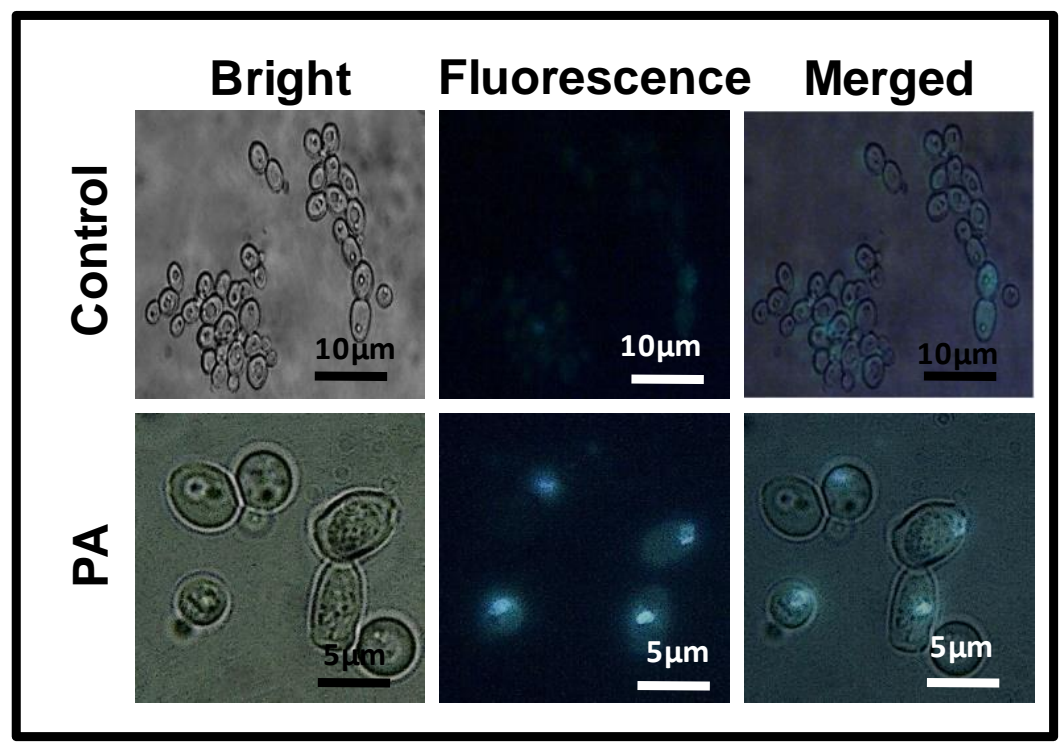

Figure 7. Effect of PA on nuclear fragmentation. Fluorescent microscopy of DAPI for detection of nuclear fragmentation in presence of PA.

\section{Conclusion}

Taken together, the antifungal potential of PA not only provides an opportunity to aid PA develop into pharmacologically acceptable and efficient antifungal but also helps in deciphering novel regulatory circuits governing drug resistance in $\mathrm{C}$. albicans. This is evident by wide range of antifungal targets of PA in comparison to single mode of action of known antifungals such as azoles. Further studies are warranted to competently employ phytotherapeutics such as PA in treating Candida infections.

\section{Acknowledgements}

S.H. thank for the financial assistance in the form of Young Scientist award (SR/FT/LS-12/2012) from Science and Engineering Research Board (SERB), New Delhi. We are grateful to Joseph Heitman for providing Candida SC5314 reference strain as generous gift. We thank Rajendra Prasad, Dean, Faculty of Science, Engineering and Technology for encouragement.

\section{References}

[1] S. Singh, Z. Fatima, S. Hameed, Infez. Med. 23(3) (2015) 211-23.

[2] G.D. Brown, D.W. Denning, N.A. Gow, S.M. Levitz, M.G. Netea, T.C. White, Sci. Transl. Med. 4(165) (2012) 165 rv113.

[3] M.A. Pfaller, D.J. Diekema, Crit. Rev. Microbiol. 36 (2010) 1-53.

[4] J. Tanwar, S. Das, Z. Fatima, S. Hameed, Interdiscip. Perspect. Infect. Dis. 2014 (2014) 541340.

[5] G.B. Zore, A.D. Thakre, S. Jadhav, S.M. Karuppayil, Phytomedicine 18(13) (2011) 1181-90.

[6] M.A. Ansari, Z. Fatima, S. Hameed, PLoS One 11(9) (2016) e0162465.

[7] T. C. Chen, C.O. Da Fonseca, AH. Schönthal, Int. J. Mol. Sci. 17(9) (2016).

[8] C.E. Oturanel, i. Kıran, Ö. Özşen, G.A. Çiftçi, Ö. Atlı, Anticancer Agents Med. Chem. 17 (2017) doi: $10.2174 / 1871520617666170103093923$.

[9] A.C. Gomes, A.L. Mello, M.G. Ribeiro, et al. Arch. Immunol. Ther. Exp. (Warsz) (2017).

[10] M.S. Khan, I. Ahmad, S.S. Cameotra, AMB Express 3(1) (2013) 54. 
[11] H. Elicharova, H. Sychrova, Med. Mycol. 51(8) (2013) 785-94.

[12] S. Singh, Z. Fatima, S. Hameed, Arch. Microbiol. 198(5) (2016) 459-72.

[13] S.S. Wong, R.Y. Kao, K.Y. Yuen, et al. PLoS One 9(1) (2014) e85836.

[14] P. Reungpatthanaphong, S. Dechsupa, J. Meesungnoen, C. Loetchutinat, S. Mankhetkorn, J. Biochem. Biophys. Methods 57(1) (2003) 1-16.

[15] B. Hao, S. Cheng, C.J. Clancy, M.H. Nguyen, Antimicrob. Agents Chemother. 57(1) (2013) 326-32.

[16] Y. Krauke, H. Sychrova, Curr. Microbiol. 61 (2010) 335-339.

[17] M.S. Cyert, C.C. Philpott, Genetics 193(3) (2013) 677-713.

[18] J. Han, M.A. Jyoti, H.Y. Song, W.S. Jang, PLoS One 11(2) (2016) e0150196.

[19] S. Yoshikawa, K. Shinzawa-Itoh, R. Nakashima, et al. Science 280(5370) (1998) 1723-9.

[20] M.W. Bowler, M.G. Montgomery, A.G. Leslie, J.E. Walker, Proc. Natl. Acad. Sci. USA 103(23) (2006) 8646-9.

[21] S.W. Perry, J.P. Norman, J. Barbieri, E.B. Brown, H.A. Gelbard, Biotechniques 50(2) (2011) 98-115.

[22] E. Gottlieb, S.M. Armour, M.H. Harris, C.B. Thompson, Cell Death Differ. 10(6) (2003) 709-17.

[23] H.L. Lin, T.Y. Liu, C.W. Wu, C.W. Chi, Cancer 92(3) (2001) 500-9. 